D) Check for updates

Cite this as: $B M J$ 2020;370:m2933 http://dx.doi.org/10.1136/bmi.m2933 Published: 22 July 2020

\section{NICE cautions against using graded exercise therapy for patients recovering from covid-19}

We have replaced the word "advises" with "cautions" in the title of this news story (BMJ 2020;370:m2912, doi:) to make it clearer that the advice was not formal guidance. 